\title{
An Assessment Of The Stock Market And Exchange Rate Dynamics In Industrialized And Emerging Markets
}

F. Beer, California State University San Bernardino, USA

F. Hebein, California State University San Bernardino, USA

\begin{abstract}
This paper adopts an Exponentional General Autoregressive Conditional Heteroskedasticity (EGARCH) framework to explore the relationship between stock prices and exchange rates for two groups of countries: emerging and developed economies. Results show that some positive significant price spillovers from the foreign exchange market to the stock market exist for Canada, Japan, the U.S and India. Findings also show for the developed countries, there is no persistence of volatility in the stock markets and the exchange rate markets. For the emerging economies, findings point to the opposite: volatility is pronounce and enduring.
\end{abstract}

Keywords: Exchange Rate Dynamics, Industrialized Markets, Emerging Markets, GARCH, Volatility Spillover

\section{INTRODUCTION}

O

ince the early 1990s, the relationship between foreign exchange markets and stock markets has fascinated many researchers and academics. What should we expect? Should we assume that changes in exchange rates affect the competitiveness of a firm, which in turn will influence its earnings or its cost of funds and hence its stock price? Or should we assume that a rising stock market would attract capital which will increase the demand for domestic currency and cause exchange rate to appreciate?

Theoretical links between stock prices and exchange rates have taken two major forms. The "Flow-oriented" models of exchange rates (Dornbusch and Fischer, 1980) concentrate on the current account of the balance of payment. These models hypothesize that exchange rates changes influence international competitiveness and trade balance, impacting real income and output. Stock prices react to exchange rate changes and create a link between current investment and consumption decisions. Innovations in the stock market impact the aggregate demand through wealth and liquidity effects, influencing money demand and exchange rates (Gavin, 1989). The second approach, the "Stock-oriented" models of exchange rates ( Branson, 1983; Frankel, 1983), focuses on the capital account as a significant determinant of exchange rate dynamics. Since the values of financial assets are determined by the present values of their future cash flows, expectations of relative currency values impact internationally held financial assets. Therefore, stock price innovations may affect, or be affected by, exchange rate dynamics.

Early empirical studies have focused on the relation between stock returns and exchange rates using U.S. data. Aggarwal (1981) finds that the US stock prices and the trade-weighted dollar value are positively correlated. Soenen and Hennigar (1988) document a strong negative correlation between US stock indexes and a fifteen currency-weighted value of the dollar. Bahmani, Oskooee and Sohrabian (1992) show that there is a positive link between stock prices measured by the S\&P 500 index and effective exchange rates of the dollar.

Newer studies investigate the relationship between stock prices and exchange rates for additional industrialized economies. Ajayi and Mougoue (1996) report significant short-run and long-run relations between the two variables for several industrial economies. Ajayi, Friedman, and Mehdian (1998) describe the relationship 
between the two variables. Their results show that in industrialized countries, it is the stock markets that impact the currency markets. Nieh and Lee (2001) find significant short-run linkage and no long-run relationship between stock prices and exchange rates for the G-7 countries. Stavarek (2005) shows a stronger causality in countries with developed capital and foreign exchange markets than in others. Yutaka (2006) focuses on relationship between exchange rate and stock price during the easing of the monetary policy in Japan.

Studies on the examination of the stochastic behavior of the stock prices and exchange rates, primarily employing auto-regressive conditional heteroskedastic (ARCH) methodology of Engle (1982). In addition, (G)ARCH model has been used to study volatility spillovers between markets in different national countries and between different assets. For example, Hamao et al. (1990) investigate the price and volatility spillovers in three major stock markets (New York, Tokyo, and London). Koutmos and Booth (1995) find asymmetric volatility spillovers across the New York, Tokyo, and London stock markets. So (2001) studies the dynamic spillover effect between interest rate and exchange value of US dollar.

Clearly, there is theoretical consensus neither on the existence of relationship between stock prices and exchange rates nor on the direction of the relationship. Understandingly, empirical studies are also inconclusive. Further, despite the rather extensive and examination of the linkages and interactions, i.e. causality, between exchange rates and stock prices, only recently have attempts been made to analyze the possibility that the transmission of volatility or volatility spillover effect can exist between the stock and currency markets in emerging markets. Kanas (2000) and Yang and Doong (2004) have studied volatility and its transmission, but the authors limit their investigation to industrialized countries.

This paper concentrates on the transmission of volatility or volatility spillover effect, it adopts an EGARCH framework and it compares the relationship between stock prices and exchange rates for two groups of countries: The United States, Canada, the U.K and Japan and five emerging Asian countries, Hong-Kong, Singapore, South Korea, India and the Philippines.

The use of EGARCH for a sample of industrialized and emerging countries, has a number of advantages. Standard GARCH models assume that positive and negative error terms have a symmetric effect on volatility. In other words, good and bad news have the same effect on the volatility in the model. In practice this assumption is frequently violated, in particular by stock returns, in that volatility increases more after bad news than after good news. EGARCH model accounts for this limitation. A comparison of the stock index returns from emerging markets exhibit different characteristics compared to those from developed markets. Harvey (1995) and Bekaert and Harvey (2002) argued that emerging market returns have higher volatility, fatter tails, and greater predictability than mature markets. In a previous study Bekaert and Harvey (1997), showed that volatilities in emerging markets are primarily determined by local information variables. Aggarwal, Inclan and Legal (1999) found that the volatilities in emerging markets exhibit large and sudden shifts. They also reported that these jump-like changes in emerging markets volatility are primarily associated with important local events.

The paper is organized as follows: section 2 reviews model specification for stationarity, cointegration, and causality: section 3 presents and discusses the data used in our analysis and the summary statistics; section 4 presents the methodology and explains the interpretation of the analytical coefficients; and section 5 discusses the results and presents conclusions from the research.

\section{LITERATURE}

Franck and Young (1972) were among the first authors to analyze the relationship between stock prices and exchange rates. Using correlation regression analyses, they reported no significant interaction. Aggarwal (1981), on the other hand, found a positive correlation between effective exchange rate of the US dollar and stock prices. In 1987, Solnik analyzed the relationship between exchange rates, interest rates and changes in inflationary expectations, on stock prices. For the nine industrialized countries investigated, Solnik did not find any significant relationship between exchange rates variations and stock prices. Contrary to Solnik (1987), Soenen and Hennigan (1988) reported strong negative interaction using monthly data of the U.S. dollar effective exchange rate and U.S. 
stock market index during 1980-1986. Jorion (1990) found a weak link between stock returns of US multinational companies and the effective US dollar exchange rate for the period 1971-1987. Ma and Kao (1990) explained differences among countries by the nature of their economies, specifically by the strength of export or import sectors. According to these researchers, an appreciating currency negatively affects the domestic stock market for a country with a large export sector and positively affects the domestic stock market for an import-dominant country.

Early empirical studies, however, omit to recognize the fact that most financial variables are non-stationary. To account for this problem, Bahmani-Oskooee and Sohrabian (1992) used co-integration to investigate the relationship between monthly data on S\&P 500 index and US dollar effective exchange rate for the period 1973-1988. They showed bi-directional causality, at least in the short run. Other papers also studying the causality between stock indices and exchange rate used the same econometric procedures have reported diverse results.

Yu (1997) investigated Hong Kong market, Tokyo market, and Singapore market for the period 1983-1994. Using daily data, he detected bi-directional relationship in Tokyo and a causality running from exchange rates to stock prices for Singapore. Abdalla and Murinde (1997) applied co-integration approach to examine stock prices exchange rates relationship in four Asian countries using data form 1985 to 1994 . Their results reject an occurrence of causality in Pakistan and Korea but support its existence in Indian and Philippines. In India the relationship occurs from exchange rates to stock prices, the opposite is found for Philippines. Bhattacharya and Mukherjee (2003) investigated the nature of the causal relationship between stock prices and macroeconomic aggregates for in India and found no significant linkage.

Chamberlain et al. (1997) focusing on the banking industry reported that US banking stock returns were responsive to exchange rates changes. They also reported that Japanese banking stock returns were not sensitive to changes in exchange rates. Griffin and Stulz (2001) also examined particular industries rather than on the whole economy. They noted that changes of weekly exchange rates had negligible impacts on industry stock indices in developed countries. Rim and Mohidin (2002) examined relations between industry indices and exchange rates using monthly data before and during the Asian financial crisis. Their findings show that industry indices had long-run positive effects on exchange rate, and exchange rate also had long-run positive effects on most indices. Short-run effects proved to be generally negative in both directions.

Ajayi et al. (1998) provided evidence to indicate unidirectional causality from the stock to the foreign exchange markets for the advanced economies (USA, Korea) and no consistent causal relations in the emerging markets (Malaysia). Pan et al. (2000) noted that exchange rates had significant effects on stock prices in seven Asian countries during 1988-1998. Similarly to Granger et al. (2000), they reported much stronger interaction during and after the financial crisis of 1997. Ramasamy and Yeung (2001) considered causality between the two markets in nine East Asian economies and realized that the direction of causality can vary according to the period of study. For the period of the entire four years of the crisis (1997-2000) all countries, apart from Hong Kong, showed that stock prices cause movements in the exchange rates.

Phylaktis and Ravazzolo (2005) studied the long-run and short-run dynamics between stock prices and exchange rates and the channels through which exogenous shocks impact these markets. Findings using co-integration methodology and multivariate Granger causality tests on a sample of Pacific Basin countries suggest that stock and foreign exchange markets are positively related and that the US stock market acts as a conduit for these links. Hau and Rey (2006) developped an equilibrium model in which exchange rates, stock prices, and capital flows are jointly determined. They show that net equity flows into the foreign market are positively correlated with a foreign currency appreciation.

\section{DATA AND SUMMARY STATISTICS}

The raw data comprises the weekly closing prices and exchange rates for four of the G-8 countries: U.S., Canada, U.K. and Japan and five Asian Emerging countries: Hong-Kong, Singapore, South-Korea, India and Philippines. Data Sources include DataStream, Yahoo finance and the World Bank. 
The stock indices are the S\&P500, S\&P TSE Composite, FTSE100, Nikkei 225, Hang Seng, Straits Times, Seoul Composite, BSE 30 and Philippines Composite Index. The exchange rates are stated in U.S. dollars per local currency and the trade weighted value of the U.S. dollar is used to proxy the exchange value of the dollar. The sample period runs from 1997 to 2004 . The weekly series are generated from the following equation:

$R_{t}=(100) *\left(\ln \left(P_{t}\right)-\ln \left(P_{t-1}\right)\right)$

Where $\ln$ is the natural logarithm operator; $\mathrm{t}$ the time period; $R_{t}$ is the return for period $t ; P_{t}$ is the index closing price for period $t$. Each return series is therefore expressed as a percentage. Modeling an index series in this manner is typical in the literature (Nelson (1991)). Further, using weekly data is justified since data of high frequency (e.g., daily or intraday) might contain too much noise, while too wide a time grid (e.g., monthly or quarterly) will not capture the information content included in stock prices and exchange rates changes.

Table 1 Panel A describes the data for the stock market indices. Table 1 Panel B presents the same statistics for the exchange rates.

Table 1: Descriptive statistics of monthly changes of stock market index and exchange rate

\begin{tabular}{|c|c|c|c|c|c|}
\hline \multicolumn{2}{|l|}{ Panel A: Stock market index } & Canada & Japan & UK & US \\
\hline \multicolumn{2}{|l|}{ Mean $(\mu)$} & 0.31 & -0.70 & -0.05 & 0.23 \\
\hline \multicolumn{2}{|l|}{ Standard deviation $(\sigma)$} & 5.24 & 5.76 & 4.52 & 4.91 \\
\hline \multicolumn{2}{|l|}{ Skewness (S) } & -1.15 & -0.25 & -0.58 & -0.58 \\
\hline \multicolumn{2}{|l|}{ kurtosis $(\mathrm{K})$} & 6.24 & 2.24 & 3.19 & 3.28 \\
\hline \multicolumn{2}{|l|}{ Jarque-Bera $(\mathrm{D})$} & $58.07 * * *$ & 3.05 & 5.13 & 5.22 \\
\hline & Hong Kong & Singapore & S. Korea & India & Philippines \\
\hline Mean $(\mu)$ & -0.17 & 0.03 & 0.22 & 0.42 & -0.41 \\
\hline Standard deviation $(\sigma)$ & 8.83 & 8.94 & 11.54 & 7.62 & 9.08 \\
\hline Skewness (S) & -0.27 & -0.06 & 0.35 & -0.17 & 0.06 \\
\hline kurtosis $(\mathrm{K})$ & 5.18 & 4.16 & 3.74 & 2.41 & 5.39 \\
\hline Jarque-Bera (D) & $18.47 * * *$ & 4.95 & 3.85 & 1.72 & $20.96 * * *$ \\
\hline
\end{tabular}

\begin{tabular}{|c|c|c|c|c|c|}
\hline \multicolumn{2}{|l|}{ Panel B: Exchange rate } & Canada & Japan & UK & US \\
\hline \multicolumn{2}{|l|}{ Mean $(\mu)$} & -0.16 & -0.11 & 0.13 & 0.02 \\
\hline \multicolumn{2}{|l|}{ Standard deviation $(\sigma)$} & 1.56 & 2.74 & 1.85 & 1.38 \\
\hline \multicolumn{2}{|l|}{ Skewness (S) } & -0.44 & -0.81 & 0.11 & -0.11 \\
\hline \multicolumn{2}{|l|}{ kurtosis $(\mathrm{K})$} & 3.33 & 4.36 & 2.93 & 4.00 \\
\hline \multicolumn{2}{|l|}{ Jarque-Bera (D) } & 3.30 & $16.52 * * *$ & 0.17 & 3.87 \\
\hline & Hong Kong & Singapore & S. Korea & India & Philippines \\
\hline Mean $(\mu)$ & 0.01 & 0.15 & 0.22 & 0.26 & 0.80 \\
\hline Standard deviation $(\sigma)$ & 0.08 & 1.69 & 5.04 & 1.09 & 2.83 \\
\hline Skewness (S) & -2.75 & -0.10 & 4.54 & 2.09 & 1.23 \\
\hline kurtosis $(\mathrm{K})$ & 23.59 & 5.55 & 33.55 & 10.66 & 8.53 \\
\hline Jarque-Bera (D) & $1665.43^{* * *}$ & $23.95 * * *$ & $3725.23 * *$ & $279.29 * * *$ & $134.30 * *$ \\
\hline
\end{tabular}

Note: $* * *$, and $* * *$ denote significance at the $10 \%, 5 \%$, and $1 \%$ level, respectively. All changes (returns) are expressed in percentages. The test statistics for skewness and excess kurtosis is the conventional $t$-statistics. The assumed density for the Jarque-Bera statistics is the normal.

The sample means for all stock markets indices are not statistically different from zero. The standard deviations for the emerging countries, however, are higher than for the industrialized countries. The standard deviations for the emerging countries (7.62 to 11.54) are at least $30 \%$ higher compared to the largest standard deviation in the industrialized countries (Japan - 5.76). Thus returns are highly volatile in emerging markets. The work of Harvey (1995) which is based on monthly data confirmed such findings. 
The measure for kurtosis shows that most return series are positively skewed and highly leptokurtic. Based on the kurtosis values, one can conclude that the stock returns do not follow a normal distribution. This hypothesis is formally tested by the Jarque-Bera test statistics. Results show that the null hypothesis of normality is clearly rejected for Canada, Hong-Kong and the Philippines. Linear dependencies may be due to some forms of market inefficiency or market structure, and non-linear dependencies may be due to autoregressive conditional heteroskedasticity.

Findings show that the means for all exchange rate markets are not statistically different from zero and that most return series are positively skewed and highly leptokurtic. Again, the Jarque Bera tests lead to the rejection of the normal distribution for Japan and all the emerging countries. As mentioned previously for the stock markets, we suspect that linear dependencies exist due to some forms of market inefficiency or market structure, and non-linear dependencies due to autoregressive conditional heteroskedasticity. Findings from Table 1 Panel B validate two of the three stylized facts that have emerged from the literature on weekly floating exchange rate (Bos, Mahieu and Van Dijk, 2000). They are martingales, they are conditionally heteroskedastic and they exhibit excess kurtosis.

\section{METHODOLOGY}

The least square model has long been the foundation of applied econometrics. The least square model, however, assumes that the expected value of the errors terms when squared is the same at any given point. This assumption, known as homoscedasticity is violated when financial data is used. The ARCH/GARCH models treat heteroskedasticity.

The autoregressive conditional heteroscedastic (ARCH) model was introduced by Engle (1982). An ARCH process is a mean zero, serially uncorrelated process with non-constant variance conditional on past information. The ARCH models have been generalized by Bollerslew (1986) into the generalized (G)ARCH model. The GARCH models allows the conditional variance to be dependent upon previous own lags. The main drawback of this model is that it cannot capture the asymmetric response of volatility to news.

It has long been recognized that the volatility of many financial assets responds differently to bad news and good news. This is especially true for stock returns. In particular, while bad news tends to increase the future volatility, good news of the same size will increase the future volatility by a smaller amount, or may even decrease the future volatility. A popular explanation for this asymmetry is the leverage effect, as first proposed by Black (1976).

A technique for incorporating asymmetries in the modeling of volatility is the EGARCH model developed by Nelson (1991). Nelson (1991) proposed an exponential GARCH or EGARCH $(p, q)$ model to capture skewness and asymmetry. In this formulation, the conditional variance is an exponential function of the previous conditional variances and excess returns.

The competing models which also capture the asymmetric effect include GJR-GARCH and Quadratic GARCH models. However, previous evidence, presented by Hamilton (1994) supports the use of the EGARCH model rather than the Quadratic GARCH. One nice feature of EGARCH model is the log form of conditional variance, thereby guaranteeing that the variance will be positive. Further, other multivariate GARCH models such as the GJR model need to have parameter restrictions to ensure the non-negativity of conditional variances. The models used are presented in equations (2) and (3).

$$
\begin{aligned}
& R_{i, t}=\beta_{i, 0}+\sum_{j=1}^{2} \beta_{i j, t-1} R_{j, t-1}+\sum_{j=1}^{2} \beta_{i j, t-2} R_{j, t-2}+\varepsilon_{i, t}, \text { for } i, j=1,2 \\
& \log \left(\sigma_{r}^{2}\right)=\chi_{i, 0}+\sum_{j=1}^{2} \gamma_{j} \log \left(\sigma_{t-j}^{2}\right)+\sum_{i=1}^{2} \alpha_{i, i}\left|\frac{\varepsilon_{t-i}}{\sigma_{t-i}}-E\left(\frac{\varepsilon_{t-i}}{\sigma_{t-i}}\right)\right|+\sum_{i=1}^{2} \delta_{i} \frac{\varepsilon_{t-k}}{\sigma_{t-k}}
\end{aligned}
$$


The lag length for the model is typically derived from the residual tests. After considering the parsimony principle and residual's white-noise property, lag two periods is selected. In the above model, $\beta_{i, 0}, \beta_{i j, t-l}$, and $\beta_{i j, t-2}$ ( $i=1$ for stock price and $i=2$ for exchange rate) are parameters to be estimated. The persistence of volatility implied by Eq. (3) is measure by $\gamma i$. If volatility persists over both lagged periods, gamma will be large and significant. The leverage effect is modeled by the parameter $\delta j$. Finally, $\alpha_{i, i}$ measures the size effect of an innovation.

\section{EMPIRICAL FINDINGS}

Table 2: Results of PP stationarity test and Johansen co-integration test

\begin{tabular}{|l|c|c|c|c|}
\hline Panel A: Results of PP stationarity test (Stock market index) \\
\hline & \multicolumn{2}{|c|}{ Level series } & \multicolumn{2}{c|}{ First differences } \\
\hline Country & No trend & With trend & No trend & With trend \\
\hline Canada & -1.76 & -1.87 & $-7.54 * * *$ & $-7.50^{* * *}$ \\
Japan & -1.97 & -1.96 & $-9.86 * * *$ & $-9.84 * * *$ \\
UK & -1.16 & -2.21 & $-9.31^{* * *}$ & $-9.33^{* * *}$ \\
US & -1.61 & -1.79 & $-9.63 * * *$ & $-9.64 * * *$ \\
Hong Kong & -2.44 & -2.35 & $-9.42^{* * *}$ & $-9.42^{* * *}$ \\
Singapore & -2.11 & -2.14 & $-9.51^{* * *}$ & $-9.50^{* * *}$ \\
S. Korea & -1.99 & -2.53 & $-7.67 * * *$ & $-7.66^{* * *}$ \\
India & -0.85 & -1.36 & $-9.01 * * *$ & $-9.14 * * *$ \\
Philippines & -2.87 & -2.57 & $-8.45^{* * *}$ & $-8.41^{* * *}$ \\
\hline
\end{tabular}

\begin{tabular}{|l|c|c|c|c|}
\hline Panel B: Results of PP stationarity test (Exchange rate) \\
\hline & \multicolumn{2}{|c|}{ Level series } & \multicolumn{2}{c|}{ First differences } \\
\hline Country & No trend & With trend & No trend & With trend \\
\hline Canada & 0.10 & -0.48 & $-6.36^{* * *}$ & $-6.90^{* * *}$ \\
Japan & -1.81 & -2.19 & $-6.66^{* * *}$ & $-6.66^{* * *}$ \\
UK & -0.31 & -0.61 & $-8.01^{* * *}$ & $-8.20^{* * *}$ \\
US & -1.68 & -0.55 & $-6.97 * * *$ & $-7.76^{* * *}$ \\
Hong Kong & -1.74 & -1.40 & $-8.60^{* * *}$ & $-8.67 * * *$ \\
Singapore & $-3.84 * * *$ & -3.16 & $-7.64 * * *$ & $-7.88^{* * *}$ \\
S. Korea & $-3.52^{* * *}$ & $-3.67 * *$ & $-5.61^{* * *}$ & $-5.67 * * *$ \\
India & $-3.65^{* * *}$ & -1.53 & $-6.74 * * *$ & $-7.69^{* * *}$ \\
Philippines & -2.53 & -3.30 & $-6.91^{* * *}$ & $-7.00^{* * *}$ \\
\hline
\end{tabular}

\begin{tabular}{|c|c|c|c|c|}
\hline \multicolumn{5}{|c|}{ Panel C: Results of Johansen co-integration test (Stock market index vs. Exchange Rate) } \\
\hline $\mathrm{H}_{0}$ & $\lambda \max$ & trace & $\lambda \max$ & trace \\
\hline & \multicolumn{2}{|c|}{ Canada } & \multicolumn{2}{|c|}{ Japan } \\
\hline $0 \leq r$ & 5.14 & 5.35 & 4.19 & 6.30 \\
\hline \multirow[t]{2}{*}{$1 \leq r$} & 0.20 & 0.20 & 2.11 & 2.11 \\
\hline & \multicolumn{2}{|c|}{ UK } & \multicolumn{2}{|c|}{ US } \\
\hline $0 \leq r$ & 10.91 & $16.12 *$ & 10.54 & 12.77 \\
\hline \multirow[t]{2}{*}{$1 \leq r$} & $5.20 *$ & $5.20 *$ & 2.24 & 2.24 \\
\hline & \multicolumn{2}{|c|}{ Hong Kong } & \multicolumn{2}{|c|}{ Singapore } \\
\hline $0 \leq r$ & 8.77 & 10.93 & 13.64 & $17.41 *$ \\
\hline \multirow[t]{2}{*}{$1 \leq r$} & 2.17 & 2.17 & 3.77 & 3.77 \\
\hline & \multicolumn{2}{|c|}{ S. Korea } & \multicolumn{2}{|c|}{ India } \\
\hline $0 \leq r$ & $21.96^{*}$ & $25.79 *$ & 13.15 & 14.24 \\
\hline $1 \leq r$ & 3.83 & 3.83 & 1.10 & 1.10 \\
\hline & \multicolumn{2}{|c|}{ Philippines } & & \\
\hline $0 \leq r$ & 6.50 & 8.66 & & \\
\hline $1 \leq r$ & 2.15 & 2.15 & & \\
\hline
\end{tabular}

Note: $H_{0}$ is the null hypothesis that the number of cointegrating vectors is less than or equal to numbers in the entries. $\lambda$ max and trace are Johansen test statistics for testing co-integration. *,**, and *** denote significance at the $10 \%, 5 \%$, and $1 \%$ level, respectively. 


\section{Stationarity And Co-Integration}

Before the above model is estimated, it is necessary to check for the stationary of the variables and possible co-integration between them. To test for stationary of the series, we use the Phillips-Perron (PP) test. To test for co-integration, we rely on the Johansen test. Table 2, Panels A, B and C depicts the results. Panel A provides information about the stock markets, Panel B the exchange rate markets and Panel C the co-integration tests.

The results are tabulated according to level data series and for first differences in the data series. Significant stationarity is marked with asterisks. Note that for stock indices (Panel A) the level data series are not stationary either for no trend or with trend. However, first differences are all significant at the $1 \%$ level for no trend or with trend. That is, when the first differences of the series are taken, the stock indices data exhibit significant stationarity. Therefore, the series are I(1) processes and they are integrated of the same order.

For exchange rates (Panel B), the data are again tabulated according to level data series and for first differences in the data series. For level series data with no trend, Singapore, S. Korea, and India exhibit significant stationarity at the $1 \%$ level. For level series data with trend, the data are not stationary (with the exception of the exchange rate in South Korea which has significant stationarity at the 5\% level) All first differences have stationarity significant at the $1 \%$ level. Therefore the series are I(1) processes and they are integrated of the same order.

The data are next examined for co-integration. Panel $\mathrm{C}$ of Table 2 depicts the results of the Johansen test. The test results show that stock market indices and exchange rates are not co-integrated at the 5\% significance level. In contrast with Bahmani-Oskooee and Sohrabian (1992) and Ajayi and Mougoue (1996), our results are consistent with Granger et al. (2000) and Nieh and Lee (2001) and Yang and Doong (2004). Based upon the results of the empirical tests for stationarity and co-integration, there is no long-run significant correlation between stock prices and exchange rates. This result is intuitively consistent.

\section{Multivariate EGARCH}

Results of the multivariate EGARCH model are reported in Table 3. Results are arranged by country.

Table 3: Results of the multivariate EGARCH model

\begin{tabular}{|c|c|c|c|c|c|c|c|c|}
\hline \multirow{2}{*}{ Parameter } & \multicolumn{2}{|c|}{ Canada } & \multicolumn{2}{c|}{ Japan } & \multicolumn{2}{c|}{ UK } & \multicolumn{2}{c|}{ US } \\
\cline { 2 - 9 } & Stock & FX & Stock & FX & Stock & FX & Stock & FX \\
\hline$\beta_{\mathrm{i}, 0}$ & 0.2168 & -0.1212 & -0.4922 & -0.1207 & -0.1286 & 0.1686 & 0.2804 & -0.0325 \\
& $(0.39)$ & $(-0.76)$ & $(-0.78)$ & $(-0.41)$ & $(-0.26)$ & $(0.87)$ & $(0.52)$ & $(-0.22)$ \\
\hline$\beta_{\mathrm{ii}, \mathrm{t}-1}$ & $0.2155^{*}$ & $-0.0637 * *$ & 0.0251 & 0.0465 & 0.0124 & -0.0225 & 0.0245 & -0.0202 \\
& $(1.91)$ & $(-1.99)$ & $(0.22)$ & $(0.91)$ & $(0.11)$ & $(-0.52)$ & $(0.22)$ & $(-0.66)$ \\
\hline$\beta_{\mathrm{ii}, \mathrm{t}-2}$ & -0.1523 & 0.0366 & 0.0880 & -0.0120 & -0.0364 & 0.0586 & -0.0847 & $0.0532 *$ \\
& $(-1.32)$ & $(1.12)$ & $(0.82)$ & $(-0.24)$ & $(-0.33)$ & $(1.35)$ & $(-0.76)$ & $(1.77)$ \\
\hline$\beta_{\mathrm{ij}, \mathrm{t}-1}$ & -0.1891 & $0.3280 * * *$ & 0.2447 & $0.3003 * * *$ & -0.0490 & 0.1598 & 0.2587 & $0.2481 * *$ \\
& $(-0.46)$ & $(2.81)$ & $(1.02)$ & $(2.67)$ & $(-0.17)$ & $(1.43)$ & $(0.61)$ & $(2.17)$ \\
\hline$\beta_{\mathrm{ij}, \mathrm{t}-2}$ & -0.2106 & -0.0401 & -0.3561 & -0.0198 & 0.0780 & -0.1450 & -0.3218 & 0.0947 \\
& $(-0.52)$ & $(-0.35)$ & $(-1.48)$ & $(-0.18)$ & $(0.28)$ & $(-1.34)$ & $(-0.73)$ & $(0.80)$ \\
\hline \multirow{2}{*}{$\chi_{i, 0}$} & $4.0700 * * *$ & $0.5871 * *$ & 3.3611 & $1.7330^{* *}$ & 0.5485 & $1.5370 * * *$ & 0.9294 & -0.2579 \\
& $(10.11)$ & $(2.076)$ & $(0.39)$ & $(2.37)$ & $(0.64)$ & $(3.34)$ & $(1.42)$ & $(-0.71)$ \\
\hline$\gamma_{\mathrm{i}}$ & $-0.5704 * * *$ & 0.0569 & 0.0445 & -0.0135 & 0.7776 & -0.0299 & $0.7798 * * *$ & 0.1447 \\
& $(-3.78)$ & $(0.26)$ & $(0.02)$ & $(-0.04)$ & $(2.48)$ & $(-0.08)$ & $(4.33)$ & $(0.32)$ \\
\hline$\alpha_{\mathrm{i}, \mathrm{I}}$ & -0.0292 & 0.0784 & -0.0054 & -0.1620 & 0.1186 & -0.4720 & -0.2869 & $0.8278 * * *$ \\
& $(-0.66)$ & $(0.40)$ & $(-0.02)$ & $(-0.78)$ & $(0.66)$ & $(-1.22)$ & $(-1.70)$ & $(3.01)$ \\
\hline$\delta_{\mathrm{i}}$ & 0.0183 & -0.0685 & 0.0004 & -0.1502 & -0.1384 & $-0.4954 * *$ & -0.1430 & -0.1538 \\
& $(0.76)$ & $(-0.38)$ & $(0.02)$ & $(-0.88)$ & $(-1.039)$ & $(-1.98)$ & $(-1.00)$ & $(-0.88)$ \\
\hline
\end{tabular}


Results of the multivariate EGARCH (Continued)

\begin{tabular}{|c|c|c|c|c|c|c|c|c|}
\hline & \multicolumn{2}{|c|}{ Hong Kong } & \multicolumn{2}{c|}{ Singapore } & \multicolumn{2}{c|}{ S.Korea } & \multicolumn{2}{c|}{ India } \\
\hline Parameter & Stock & FX & Stock & FX & Stock & FX & Stock & FX \\
\hline$\beta_{\mathrm{i}, 0}$ & -0.0988 & 0.0045 & -0.1639 & 0.1037 & 0.1093 & 0.1505 & 0.8259 & 0.2023 \\
& $(-0.10)$ & $(0.49)$ & $(-0.17)$ & $(0.57)$ & $(0.10)$ & $(0.33)$ & $(0.93)$ & $(1.64)$ \\
\hline$\beta_{\mathrm{ii}, \mathrm{t}-1}$ & 0.0669 & 0.0007 & 0.0828 & 0.0000 & $0.3225 * * *$ & 0.0610 & -0.0376 & -0.0200 \\
& $(0.60)$ & $(0.61)$ & $(0.64)$ & $(0.01)$ & $(2.91)$ & $(-1.35)$ & $(-0.33)$ & $(-1.26)$ \\
\hline$\beta_{\mathrm{ii}, \mathrm{t}-2}$ & -0.0639 & -0.0008 & 0.1299 & -0.0176 & 0.0428 & $-0.0748^{*}$ & 0.1117 & -0.0129 \\
& $(-0.59)$ & $(-0.7916)$ & $(1.02)$ & $(-0.76)$ & $(0.42)$ & $(-1.80)$ & $(0.98)$ & $(-0.82)$ \\
\hline$\beta_{\mathrm{ij}, \mathrm{t}-1}$ & -13.1827 & 0.0448 & 0.4954 & 0.2223 & $1.3035^{* * *}$ & $0.5300^{* * *}$ & -0.5470 & $0.2330^{* *}$ \\
& $(-1.13)$ & $(0.39)$ & $(0.70)$ & $(1.71)$ & $(4.82)$ & $(4.81)$ & $(-0.66)$ & $(2.02)$ \\
\hline$\beta_{\mathrm{ij}, \mathrm{t}-2}$ & 12.0522 & -0.0717 & 0.4954 & -0.1876 & $-0.6407 * *$ & $-0.2433 * *$ & -0.4954 & -0.0320 \\
& $(1.01)$ & $(-0.62)$ & $(0.70)$ & $(-1.46)$ & $(-2.24)$ & $(-2.09)$ & $(-0.61)$ & $(-0.28)$ \\
\hline$\chi_{i, 0}$ & $3.7615 * * *$ & -5.936 & 1.4990 & $-0.4053 * * *$ & $7.7399 * * *$ & -0.098 & $2.3380^{* *}$ & $-1.4146 * * *$ \\
& $(2.67)$ & $(-2.54)$ & $(1.78)$ & $(-2.778)$ & $(17.31)$ & $(-0.80)$ & $(2.36)$ & $(-8.35)$ \\
\hline$\gamma_{\mathrm{i}}$ & 0.0169 & 0.1369 & $0.5284 * *$ & $0.8348 * * *$ & $-0.7000^{* * *}$ & $0.7801 * * *$ & $0.4930^{* *}$ & $0.7765 * * *$ \\
& $(0.05)$ & $(0.38)$ & $(2.76)$ & $(6.51)$ & $(-10.43)$ & $(16.30)$ & $(2.21)$ & $(7.05)$ \\
\hline$\alpha_{\mathrm{i}, \mathrm{j}}$ & $0.5514 * *$ & $1.0283 * * *$ & $0.6666^{* * *}$ & $0.6316^{* * *}$ & $-0.0381 * *$ & $0.7307 * * *$ & $-0.4007 *$ & $1.6897 * * *$ \\
& $(1.77)$ & $(4.30)$ & $(2.92)$ & $(3.00)$ & $(-2.03)$ & $(4.12)$ & $(-1.81)$ & $(5.81)$ \\
\hline$\delta_{\mathrm{i}}$ & $0.3645 * * *$ & -0.0736 & 0.0343 & 0.1106 & $0.0566 * * *$ & $0.4038^{* * *}$ & 0.0327 & -0.2040 \\
& $(2.68)$ & $(-0.37)$ & $(0.25)$ & $(0.85)$ & $(2.85)$ & $(2.84)$ & $(0.57)$ & $(-0.94)$ \\
\hline
\end{tabular}

\section{Results of the multivariate EGARCH model (Continued)}

\begin{tabular}{|c|c|c|}
\hline \multicolumn{2}{|c|}{ Philippines } & FX \\
\hline Parameter & Stock & $0.5615^{* *}$ \\
$(2.03)$ \\
\hline$\beta_{\mathrm{i}, 0}$ & -0.3973 & $-0.0616^{*}$ \\
& $(-0.40)$ & $(-1.94)$ \\
\hline$\beta_{\mathrm{ii}, \mathrm{t}-1}$ & 0.2226 & $-0.0599^{*}$ \\
& $(1.94)$ & $(-1.87)$ \\
\hline$\beta_{\mathrm{ii}, \mathrm{t}-2}$ & -0.0238 & $0.2110^{*}$ \\
& $(-0.21)$ & $(1.95)$ \\
\hline$\beta_{\mathrm{ij}, \mathrm{t}-1}$ & 0.1238 & $-0.1373^{*}$ \\
& $(0.32)$ & $(-1.35)$ \\
\hline$\beta_{\mathrm{i}, \mathrm{t}-2}$ & 0.2228 & $0.1461^{* *}$ \\
& $(0.61)$ & $(2.04)$ \\
\hline$\chi_{i, 0}$ & $7.1775 * * *$ & $1.004^{* * *}$ \\
\hline$\gamma_{\mathrm{i}}$ & $(10.08)$ & $(34.19)$ \\
\hline$\alpha_{\mathrm{i}, \mathrm{j}}$ & -0.7703 & $-0.2461^{* * *}$ \\
\hline$\delta_{\mathrm{i}}$ & $(-4.60)$ & $(-3.10)$ \\
\hline
\end{tabular}

Note: The numbers in the parentheses are the t-statistics with robust standard errors. *, **, and *** denote significance at the $10 \%, 5 \%$, and $1 \%$ level, respectively.

Results show that with the exception of Canada and South Korea, all countries stock markets $\beta i i, t-1$ coefficients are equal to zero. Without Canada and the Philippines, all countries foreign exchange markets $\beta$ ii, $t-1$ coefficients are also equal to zero. As far as $\beta i i, t-2$, are concerned, the coefficients estimated are only significant in the U.S, South Korea and the Philippines for the exchange rate markets. None of the coefficients are different from zero for the stock markets. Coefficients equal to zero indicate that asset prices are rationally related to economic realities and incorporate all available information. This implies the absence of exploitable excess profit opportunities. 
The significant $\beta i j, t-1$ coefficients for Canada, Japan, the U.S., South Korea, India and the Philippines suggest some price spillovers from the foreign exchange markets to the stock markets. Positive and significant coefficients hint that when a currency depreciated a decline in stock prices is expected as depreciation suggests higher inflation in the future which makes investors skeptical about future performance of companies.

Results show very little persistence of volatility for the stock markets and the exchange rate markets for the developed sample of countries. Results, however, indicate the opposite for the emerging countries sampled, the large majority of $\gamma i$ are positive and significant. Divergent results are also observed for the $\alpha_{i, i}$. Most parameters are positive and significant for the emerging markets economies but not significant for the developed countries. Finally, the $\delta j$, indicating the presence of the leverage effect, are significant but atypically positive for the stock markets of Hong-Kong and South Korea and the exchange rate markets of the Philippines and Korea.

\section{SUMMARY AND CONCLUDING REMARKS}

The paper explored the interaction between stock prices and exchange rates using EGARCH for nine countries: U.S., Canada, U.K. and Japan and five Asian Emerging countries: Hong-Kong, Singapore, South-Korea, India and Philippines.

Findings for the stock market indices reveal the non-stationary of all observations. When the first differences of the series are taken, the PP test statistics become significant. Therefore, the series are $I(1)$ processes and they are integrated of the same order. For the exchange rates, results are similar with the exception of Singapore, South Korea and India. Accordingly, most exchange rates series are also I(1) processes. Results of the Johansen test indicates that with the elimination of the U.K., Singapore and South-Korea, the stock market indices and exchange rates are not co-integrated.

Statistically, the hypothesis that the lagged coefficients for the stock series and the exchange rate series are not different from zero cannot be rejected for most industrialized and emerging countries. These first observations do not permit to invalidate the efficient market hypothesis for both samples of countries. It thus appears that asset prices are rationally related to economic realities and incorporate all information available to the market. This implies the absence of exploitable excess profit opportunities.

Evidence from the first moment inter-dependence, shows some positive significant price spillovers from the foreign exchange market to the stock market for Canada, Japan, the U.S, India and South Korea. In these countries, currency depreciation leads to a decline in stock prices as depreciation suggests higher inflation in the future which makes investors skeptical about future performance of companies. For some countries, the negative sign of coefficient renders economic interpretation difficult.

For the developed sample, we do not detect a strong persistence of volatility in the stock markets and the exchange rate markets. For the emerging economies, findings indicate the opposite: volatility is more pronounce and enduring. Our results also indicate that for Hong-Kong stock market, the Philippines exchange rate market and the stock and exchange rate markets of Korea the asymmetric parameters, $(\delta j)$, are significant but positive, indicating that positive shocks increase volatility more than negative shocks of an equal magnitude. Generally, developed markets display a negative asymmetric parameter. Although this could be the result of the distributional features of the returns of these markets, it is possible that markets inefficiencies, markets frictions, and investors relative lack of experience induce more volatility when good news are reported. This result, consistent with the findings of Koutmos (1992) and Koutmos, et al., (1993), seems to characterize emerging markets.

Interestingly, the impact of the size of the innovation of the stock markets and the exchange markets is significant in all the Asian countries and only in the exchange rate market for the U.S. For all the other countries, since the $\alpha_{i, j}$ are not significant there is no difference between negative and positive innovations. 
To sum-up, the comparison between developed and emerging economies undertaken in this study should be used by international portfolio managers, governments and individual investors alike. In some economies currency depreciation impact stock prices. In emerging economies, volatility is enduring, good news significantly impact volatility and the size of the innovation must be taken in to account as it also considerably fuel volatility. This should be particularly important to international investors and managers when devising hedging and diversification strategies for their portfolios.

Of course, we know that with regards to data and interpretation of the data, statistical problems existed. Firstly, for emerging economies, the quality of the data is sometimes questionable. Secondly, for these economies, regime shifts during the sample period might complicate the interpretation of empirical results over the entire sample period. Currencies used to be fixed, but flexible exchange rate systems are now common in many emerging economies. These factors prevent us from drawing definite and strong conclusions that only continuous studies of these important issues will allow to reach.

\section{REFERENCES}

1. Abdalla, I. S. A., Murinde, V. (1997) "Exchange Rate and Stock Price Interactions in Emerging Financial Markets: Evidence on India, Korea, Pakistan, and Philippines", Applied Financial Economics, 7, 25-35.

2. Aggarwal, R. (1981) "Exchange Rates and Stock Prices: A Study of thee US Capital Markets under Floating Exchange Rates," Akron Business and Economics Review, 7-12

3. Aggarwal, R. Inclan, C., Leal, R. (1999) "Volatility in Emerging Stock Markets," Journal of Financial and Quantitative Analysis, Issue 34, 33-55

4. $\quad$ Ajayi, R. A., Friedman, J., \& Mehdian, S.M. (1998) "On the Relationship between Stock Returns and Exchange Rates: Tests of Granger Causality," Global Finance Journal, Volume 9, Issue 2, 241-251

5. Ajayi, R. A., Mougoue (1996) "On the Dynamic Relation between Stock Prices and Exchange Rates," The Journal of Financial Research, 2, 193-207

6. Bahmani-Oskooee, M., Sohrabian A. (1992) "Stock Prices and the Effective Exchange Rate of the Dollar," Applied Economics, Volume 24, Issue 4, 459-464

7. Bekaert, G., Geert, Harvey, C.R., Campbell, R. (2002) "Research in Emerging Markets Finance: Looking to the Future," Emerging Markets Review, Volume 3, Issue 4, 429-448

8. Bekaert, G., Harvey, C.R. (1997) "Emerging Equity Market Volatility," Journal of Financial Economics, Volume 43, 29-77

9. Bhattacharya,B. and Mukherjee, J. (2003) "Casual Relationship between Stock Market and Exchange Rate, Foreign Exchange Reserves and Value of Trade Balance: A case study for India," www.igidr.ac.in, Paper Presented at the $5^{\text {th }}$ Annual Conference on Money and Finance in the Indian Economy on January 2003

10. Black, F. (1976) "Studies of Stock Price Volatility Changes," Proceedings of the 1976 Meetings of the Business and Economics Statistics Section, American Statistical Association, 171-181

11. Bollerslev, T. (1986) "Generalized Autoregressive Conditional Heteroskedasticity," Journal of Econometrics, Volume 31, 307-327

12. Bos, C.S., Mahieu, R.J., and Van Dijk, H.K. (2000) "Daily Exchange Rate Behavior and Hedging of Currency Risk," Journal of Applied Econometrics, Volume 15, Issue 6, 671-696

13. Branson, W. H., (1983), "Macroeconomic Determinants of Real Exchange Risk," in Managing Foreign Exchange Risk, R. J. Herring ed., Cambridge University Press, Cambridge, MA.

14. Cajueiro, D.O., AND Tabak, B.M. (2004) "Ranking Efficiency for Emerging Markets," Chaos, Solitons and Fractals, Volume 22, Issue 2, 349-352

15. Chamberlain, S., Howe, J.S., Popper, H. (1997) “The Exchange Rate Exposure of U.S. and Japanese Banking Institutions", Banking and Finance, 21, 871-92.

16. Dornbusch, Rudiger and Stanley Fischer, (1980), "Exchange Rates and the Current Account," American Economic Review, v70(5), 960-971.

17. Engle, R. F., (1982), "Autoregressive Conditional Heteroscedasticity with Estimates of the Variance of United Kingdom Inflations," Econometrica, v50(4), 987-1008.

18. Frank, P. and Young, A. (1972) "Stock Price Reaction of Multinational Firms to Exchange Realignments," Financial Management, Winter, 66-73 
19. Frankel, J. A., (1983), "Monetary and Portfolio-balance Models of Exchange Rate Determination," in Economic Interdependence and Flexible Exchange Rates, J. S. Bhandari and B. H. Putnam ed., MIT Press, Cambridge, MA.

20. Gavin, M. (1989) "The Stock Market and Exchange rate dynamics," Journal of International Money and Finance, Volume 8, Issue 2, 181-200

21. Granger, C.W., Huang, B., Yang, C. (2000) “A Bivariate Causality between Stock Prices and Exchange Rates: Evidence from Recent Asian Flu”, The Quarterly Review of Economics and Finance, 40, 337-54.

22. Griffin, J.M., Stulz, R.M. (2001) "International Competition and Exchange Rate Shocks: A Cross-country Industry Analysis of Stock Returns", The Review of Financial Studies, 14, 215-41.

23. Hamao, Yasushi, Ronald W. Masulis and Victor Ng, (1990), "Correlations in Price Changes and Volatility across International Stock Markets," Review of Financial Studies, v3(2), 281-308.

24. Hamilton, J. D., (1994), Time Series Analysis, Princeton University Press, Princeton, New Jersey.

25. Hau, Herald and Rey Helene (2006), "Exchange Rates, Equity Prices, and Capital Flows", Review of Financial Studies, 19(1), 273-317

26. Kanas A. (2000), "Volatility Spillovers Between Stock returns and Exchange Rate Changes: International Evidence", Journal of Business Finance and Accounting, 27 (3), April 2000, 447-467

27. Jorion, P., (1990) “The Exchange Rate Exposure of U.S. Multinationals," Journal of Business, Volume 63, Issue 3, 331-345.

28. Harvey, C.R. and Cambell, R. (1995) "Predictable Risk and Returns in Emerging Markets," The Review of Financial Studies, Volume 8, 773-816

29. Koutmos, G. (1992) “Asymmetric Volatility and Risk Return Tradeoff in Foreign Stock Markets,” Journal of Multinational Financial Management, Volume 2, Issue 2, 27-43

30. Koutmos, Gregory and G. Geoffrey Booth, (1995), "Asymmetric Volatility Transmission in International Stock Markets," Journal of International Money and Finance, v14(6), 747-762.

31. Koutmos, G., Nrgakis, C. and Theodossiou, P. (1993) "Stochastic Behavior of the Athens Stock Exchange," Applied Financial Economics, Volume 3, Issue 2, 119-126

32. Nelson, Daniel B., (1991), "Conditional Heteroskedasticity in Asset Returns: A New Approach," Econometrica, v59(2), 347-370.

33. Nieh, Chien-Chung and Cheng-Few Lee, (2001), "Dynamic Relationships between Stock Prices and Exchange Rates for G-7 Countries," Quarterly Review of Economics and Finance, v41(4), 477-490.

34. Ma, K.C. and Kao, G.W. (1990) "On Exchange Rate Changes and Stock Price Reactions," Journal of Business Accounting, Volume 17, Issue 3, 441-449

35. Pan, M.S., Fok, R.C.W., Liu, Y.A. (2001) "Dynamic Linkages between Exchange Rates and Stock Prices: Evidence from Pacific Rim Countries", Working Paper at College of Business Shippensburg University.

36. Phillips, P.C.B. and Durlauf, S.N. (1986), "Multiple Time Series Regression with Integrated Processes," Review of Economic Studies, Volume 53, Issue 4, Econometric Special Issue, 473-495

37. Phylaktis, K., Ravazzolo, F. (2000) "Stock Prices and Exchange Rate Dynamics", Paper presented at the EFMA 2000 Meeting in Athens.

38. Kate Phylaktis, Kate and Ravazzolo, Fabiola (2005), "Stock prices and exchange rate dynamics", Journal of International Money and Finance, Volume 24, Issue 7, 1031-1053

39. Ramasamy, B., Yeung, M. (2001) "The Causality Between Stock Returns and Exchange Rates: Revisited”, The University of Nottingham in Malaysia - Division of Business and Management Research Paper Series, Paper No. 2001-11

40. Rim, H.K. and Mohidin, R. (2002) "Study on the Effects of Exchange Rate on Idustry Indices in Malaysia," The H.R. Frehn Center for Management Working Paper, WP 2002-a, Access from www: $\langle\underline{\text { http://grove.shipiedu/reserach/wp/wp2002_pdf }>}$

41. So, Raymond W., (2001), "Price and Volatility Spillovers between Interest Rate and Exchange Value of the US Dollar," Global Finance Journal, v12(1), 95-107

42. Soenen, L. and E. Hennigar, (1988), "An Analysis of Exchange Rates and Stock Prices - the US Experience between 1980 and 1986," Akron Business and Economic Review, 19, 7-16.

43. Solnik, Bruno, (1987), "Using Financial Prices to Test Exchange Rate Models: A Note," Journal of Finance, v42(1), 141-149 
44. Stavarek, Daniel, (2005), "Stock Prices and Exchange Rates in the EU and the USA: Evidence on their Mutual Interactions", Working paper, 1-26

45. Yang, S-Y and S.-C. Doong (2004), "price and Volatility Spillovers between Stock process and Exchange Rates: Empirical Evidence from G-7 Countries", International Journal of Business and Economics, Vol.3, n2, 139-153

46. Yu,Q. (1997) "Stock Prices and Exchange Rates: Experience in Leading East Asian Financial Centres: Tokyo, Hong Kong and Singapore", Singapore Economic Review, 41, 47-56.

47. Yutaka, Kurihara (2006), "Relationship between Exchange Rate and Stock Prices during the Quantitative Easing Policy in Japan", The International Journal of Business, 1-12.

\section{NOTES}

